\title{
Ustilago vuyckii found in Australia
}

\author{
LEENA HÄMET-AHTI
}

\begin{abstract}
HÄMET-AHTI, L. 1982: Ustilago vuyckii found in Australia. — Karstenia 22: 17-19.
The smut fungus Ustilago vuyckii Oudem. \& Beijer. has been found for the first time in the southern hemisphere, on Luzula novae-cambriae Gandoger in Victoria, Australia. The total range of $U$. vuyckii is mapped.
\end{abstract}

Leena Hämet-Ahti, Department of Botany, University of Helsinki, Unioninkatu 44, SF00170 Helsinki 17, Finland.

Ustilago vuyckii Oudem. \& Beijer. in Oudem. is described from the Netherlands and causes a systemic infection on several Luzula species in the northern hemisphere (Fig. 1; cf. also Hämet-Ahti 1972, 1979 and the literature cited therein). Most authors have used the spelling 'vuijckii'. However, the correct spelling is 'vuyckii' as shown by Walker (1971: 106).

$U$. vuyckii also occurs in Australia, where it was detected on a Luzula specimen, viz. L. novae-cambriae Gandoger, collected in Victoria. This specimen consists of six individuals of Luzula; two of them are infected by the smut and their capsules are filled with its characteristic yellow spore mass. The size of the spores varies from 12 to $19 \mu \mathrm{m}$ (mounted in lactophenol). The values agree with those obtained in the northern hemisphere (Walker 1971, Hämet-Ahti 1972, 1979). The spores are subglobose to subelliptic, yellow to light brown and deeply reticulate (Fig. 2), appearing spiny at the circumference under the light microscope. In the SE micrographs the surface reticulation of the Australian specimen seems to be slightly coarser than in the North American material (Fig. 3). However, the Australian spores are obviously younger than the fully mature American ones, and the

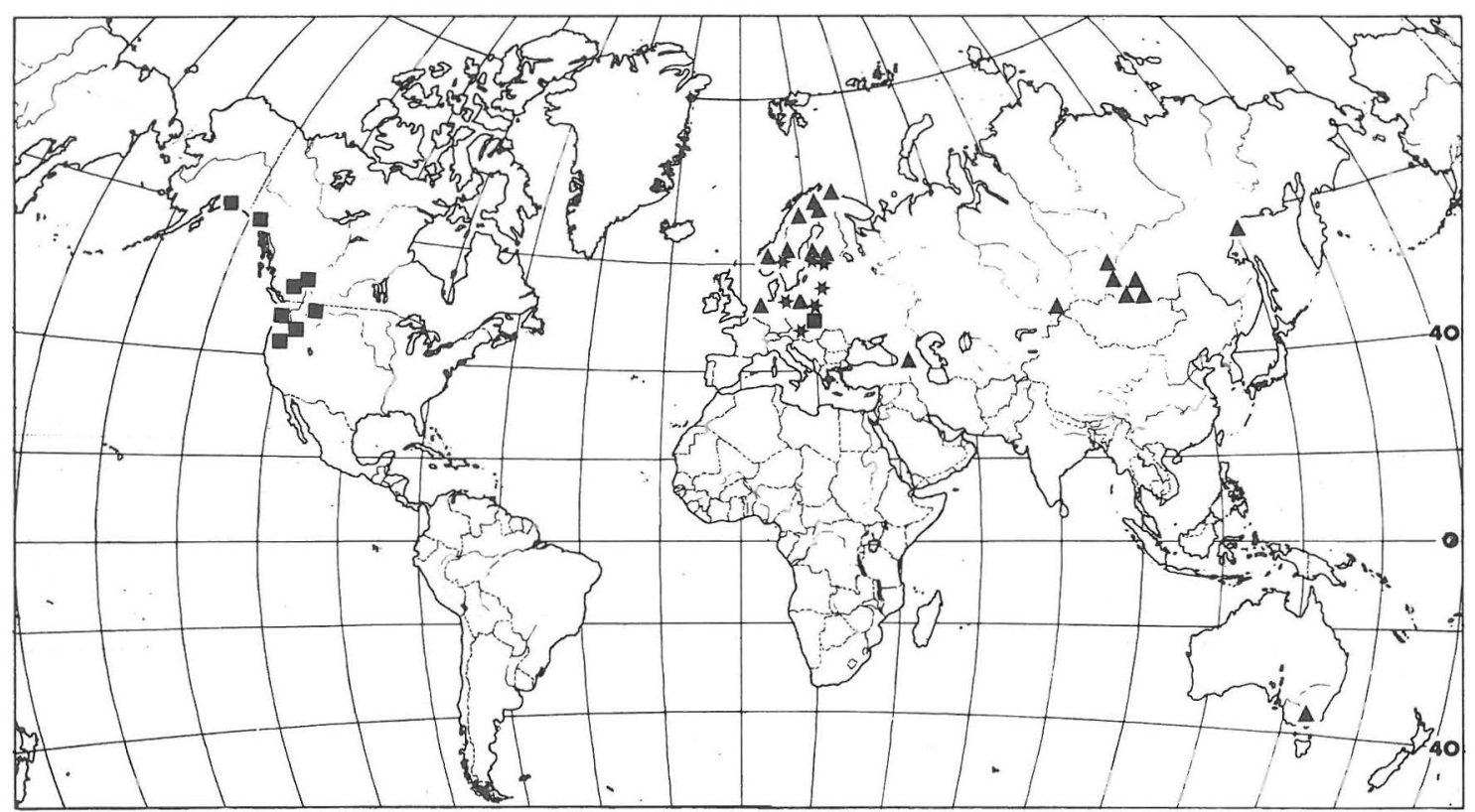

Fig. 1. The total distribution of Ustilago vuyckii and its occurrence on the species of the subgenera Anthelaea (square), Pterodes (asterisk) and Luzula (triangle) of the genus Luzula. 

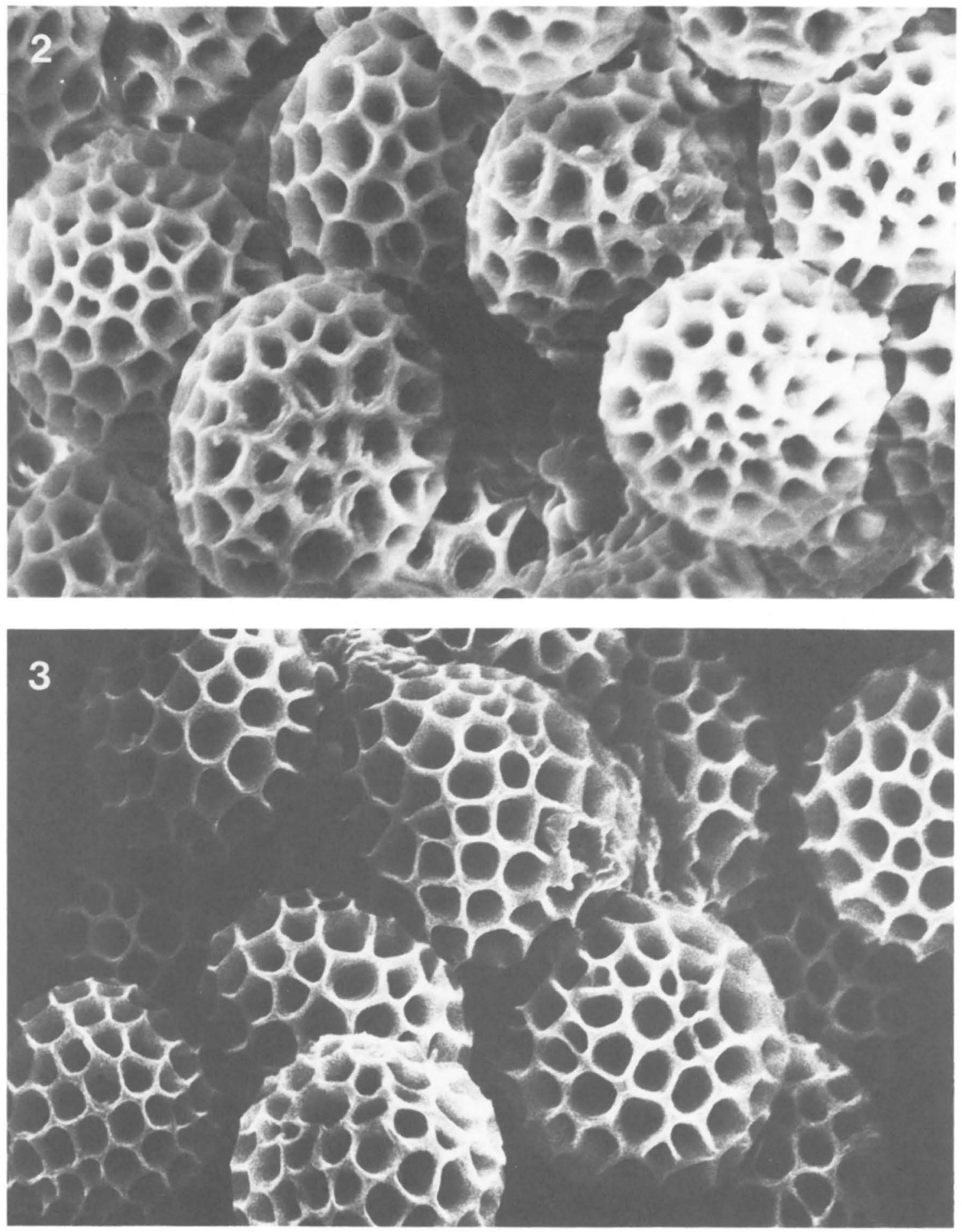

Figs. 2-3. SE micrographs of the spores of Ustilago vuyckii. - 2. On Luzula novae-cambriae (Australia, Victoria, Beauglehole \& Chesterfield 40781; MEL). - 3. On L. parviflora (Canada, Yukon, Hämet-Ahti 417a; H). - Magnification: $\times 2000$. 
spores from the two regions are quite indistinguishable.

The infected individuals of $L$. novae-cambriae have shorter capsules than the uninfected ones; also, their anthers have remained closed. Both these features are conspicuous symptoms of the presence of $U$. vuyckii (cf. Hämet-Ahti 1972). Whether the anthers contained conidia could not be checked, but it is highly probable (cf. Oudemans 1895, Liro 1924, Hämet-Ahti 1972). The influence of the smut on this specimen seems to be confined to the flowers; both the inflorescence and the vegetative parts appear quite normal.

Until now $U$. vuyckii has been found on about 10 species or races of Luzula (e.g. Liro 1924, 1938, Gutner 1941, Zundel 1953, Lindeberg 1959, Jörstad 1963, Scholz 1968, Ul'yanishchev 1968, Hämet-Ahti 1972, 1979, Ignatavichyote 1975). These belong to three subgenera, viz. Luzula (Gymnodes), Pterodes and Anthelaea. However, it is curious that all the known North American finds are on the species of Anthelaea, while in Eurasia the fungus primarily grows on the species of Luzula and Pterodes, the only exception being one find on L. (Anthelaea) alpinopilosa in Poland. To some extent this situation may be due to the fact that this smut is easily overlooked by mycologists, but I have checked fairly extensive material of the subgenus Anthelaea, for instance, from eastern North America and northern Eurasia without finding $U$. vuyckii. L. novae-cambriae belongs to the subgenus Luzula, a variable and taxonomically complicated group in Australasia (cf. Edgar 1975).

In the northern hemisphere most of the $U$. vuyckii specimens were collected in the boreal or oroboreal areas. A few come from the oroarctic habitats in western North America and some from the temperate areas in Central Europe. In Australia the only known locality is on the top of Mt. Howitt (alt. ca. $1740 \mathrm{~m}$ ). The S.E. Australian mountain areas between 1400 and $1800 \mathrm{~m}$ have been included in a 'subalpine' vegetation zone (cf. Costin 1981), which apparently — at least in its upper part - corresponds bioclimatically to the boreal vegetation in the northern hemisphere. The Australian subalpine areas have a distinctly oceanic climate with high rainfall (Costin 1981). The greater part of the range of $U$. vuyckii in the northern hemisphere may also be regarded as oceanic. Eastern Siberia is admittedly continental, but all the known localities of $U$. vuyckii are in the river valleys (cf. Hämet-Ahti 1972), where the local climate is presumably less continental.

Specimen examined: Australia. Victoria (S16): Mt. Howitt, on top, 1972 Beauglehole \& Chesterfield 40781 (MEL 1516444).

Acknowledgements. I am grateful to the curators of the National Herbarium of Victoria (MEL), Melbourne, for the loan of the specimen and for their help during my visit, to Dr. J. Walker, Rydalmere, N.S.W. for his advice, and to Dr. Maire Pyykkö, Helsinki, for the SE micrographs.

\section{References}

Costin, A.B. 1981: Alpine and sub-alpine vegetation. In: R.H. Groves (ed.), Australian vegetation: $361-376$. 499 pp. Cambridge etc.

Edgar, E. 1975: Australasian Luzula. - New Zealand J. Bot. 13: $781-802$.

Gutner, L.S. 1941: Golovnevye griby (po materialam A.A. Yachevskogo). - 383 pp. Moskva \& Leningrad.

Hämet-Ahti, L. 1972: Notes on Ustilago vuijckii Oudem. and Beijer. on some Luzula species in North America. Syesis 5: 83-85.

- 1979: Ustilago vuijckii Oud. et Beijer. na Luzula multiflora subsp. sibirica i L. pseudosudetica iz Aziatskoy chasti SSSR. - Novitates System. Plant. Non Vascul. 16:113-114.

Ignatavichyote, M. 1975: Golovnevye griby Pribaltiki. $277 \mathrm{pp}$. Vilnius.

Jörstad, I. 1963: Ustilaginales of Norway. - Nytt Mag. Bot. 10: $85-130$.

Lindeberg, B. 1959: Ustilaginales of Sweden (exclusive of the Cintractias on Caricoidae). - Symb. Bot. Upsalienses $16(2): 1-175$.

Liro, J.I. 1924: Die Ustilagineen Finnlands 1. - Ann. Acad. Sci. Fennicae (Ser. A) 17: 1-636.

- 1938: Die Ustilagineen Finnlands 2. - Ann. Acad. Sci. Fennicae (Ser. A) 49: 1-720.

Oudemans, C.A.J.A. 1895: Over twee nog onbekende fungi: Septoria Dictyotae en Ustilago Vuyckii. - Versl. Zitt. Wis- en Natuurk. Afd. Akad. Wetensch. 3: 54-57.

Scholz, H. 1968: Brandpilze (Ustilaginales) aus Brandenburg und Berlin 1912-1968. - Verh. Bot. Ver. Brandenburg 105: 3-31.

Ul'yanishchev, V.I. 1968: Opredelitel' golovnevykh gribov SSSR. - 182 pp. Leningrad.

Walker, J. 1971: An undescribed species of Ustilago on Cyperus lucidus R.Br. in Australia. - Proc. Linnean Soc. New South Wales 96(2): 99-107.

Zundel, G.L. 1953: The Ustilaginales of the world. - Contr. Dept. Bot. Pennsylvania State Coll. 176: $1-410$. 